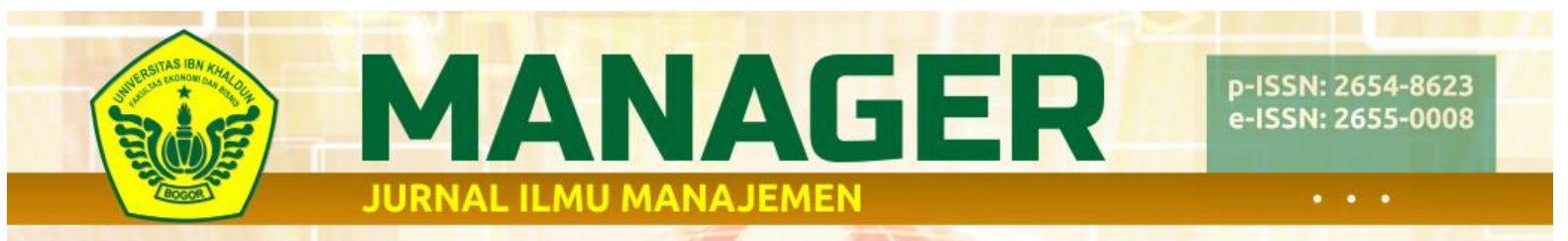

Vol. 3, No. 2, Mei 2020, Hal 199-208 (c) (1) (1)

http://ejournal.uikabogor.ac.id/index.php/Manager/index

\title{
PENGARUH DISIPLIN DAN BUDAYA ORGANISASI TERHADAP PRESTASI KERJA PEGAWAI
}

\author{
Dini Fikriani, M. Azis Firdaus, Rachmatullaily Tinakartika Rinda \\ Fakultas Ekonomi dan Bisnis Universitas Ibn Khaldun Bogor, Indonesia \\ dinifkrn@gmail.com, azisfirdaus@gmail.com, lailyrinda@yahoo.com
}

\begin{abstract}
The purpose of this research was to determine how much influence the Discipline and Organizational Culture had on Employee Performance in the Bogor Industry and Trade Office at Bogor City. This study uses a survey method using primary data obtained from questionnaires and the samples used in this study were 51 respondents. The results of the correlation analysis between Discipline and Organizational Culture on Work Performance amounted to 0,752, this shows a strong relationship. The adjusted coefficient of determination shows 54,8\% which means that the magnitude of the influence of Discipline $\left(X_{1}\right)$ and Organizational Culture $\left(X_{2}\right)$ on Work Performance $(Y)$ of 54,8\% while the remaining $45,2 \%$ is influenced by other factors that are not included in this study. The regression equation is $Y=2,472+0,597 X_{1}+0,386 X_{2}$. Because $F$ count $=31,256>F$ table $=3,19$ then $\mathrm{Ho}$ is rejected (Ha accepted) means that there is a significant influence between Discipline $\left(X_{1}\right)$ and Organizational Culture $\left(X_{2}\right)$ on Work Performance $(Y)$.

Keywords: Discipline, Organizational Culture and Work Achievement.
\end{abstract}

\begin{abstract}
Abstrak
Penelitian ini bertujuan untuk mengetahui seberapa besar pengaruh Disiplin dan Budaya Organisasi terhadap Prestasi Kerja Pegawai pada Dinas Perindustrian dan Perdagangan Kota Bogor. Penelitian ini menggunakan metode survei dengan menggunakan data primer yang diperoleh dari kuesioner dan sampel yang digunakan dalam penelitian ini sebanyak 51 responden. Hasil analisis korelasi Disiplin dan Budaya Organisasi terhadap Prestasi Kerja sebesar 0,752 hal ini menunjukan hubungannya kuat. Koefisien Determinasi yang disesuaikan menunjukan sebesar 54,8\% memberikan arti bahwa besarnya pengaruh Disiplin $\left(\mathrm{X}_{1}\right)$ dan Budaya Organisasi $\left(\mathrm{X}_{2}\right)$ terhadap Prestasi Kerja $(\mathrm{Y})$ sebesar 54,8\% sedangkan sisanya 45,2\% dipengaruhi oleh faktor-faktor lain yang tidak dimasukan dalam penelitian ini. Persamaan regresinya $\mathrm{Y}=2,472+0,597 \mathrm{X}_{1}+0,386 \mathrm{X}_{2}$. Karena $\mathrm{F}_{\text {hitung }}=31,256>\mathrm{F}$ tabel $=$ 3,19 maka Ho ditolak (Ha diterima) berarti bahwa terdapat pengaruh yang signifikan antara Disiplin $\left(\mathrm{X}_{1}\right)$ dan Budaya Organisasi $\left(\mathrm{X}_{2}\right)$ terhadap Prestasi Kerja $(\mathrm{Y})$.

Kata kunci : Disiplin, Budaya Organisasi dan Prestasi Kerja.
\end{abstract}




\section{Pendahuluan}

Latar Belakang

Memasuki era industri 4.0 persaingan antar negara semakin ketat. Hal ini merupakan tantangan bagi Indonesia untuk meningkatkan kinerja dan daya saing. Masalah nasional yang harus diselesaikan oleh Indonesia saat ini yaitu peningkatan kualitas sumber daya manusia. Hal ini dapat dilihat dari Indeks Sumber Daya Manusia (Human Capital Index) 2018 yang dikeluarkan Bank Dunia, Indonesia menempati posisi ke-87 dari 157 negara dengan skor sebesar 0,53. Posisi Indonesia masih lebih rendah jika dibandingkan dengan negaranegara di Asia Timur dan Asia Pasifik, mengingat rata-rata sejumlah negara itu sebesar 0,62 (Andreas, t.t.).

Era industri 4.0 yang ditandai dengan digitalisasi global akan membawa resiko di pasar tenaga kerja. Hal ini merupakan tantangan bagi sumber daya manusia di Indonesia. Pengelolaan manajemen sumber daya manusia dalam suatu organisasi merupakan suatu hal yang sangat penting. Untuk mencapai suatu tujuan organisasi diperlukan manajemen yang baik untuk mengatur manusia secara efektif dan efisien. Kemajuan atau kemunduran suatu organisasi merupakan akibat dari kualitas dan tingkah laku manusia yang ada di dalam organisasi tersebut.

Prestasi kerja merupakan hal yang penting yang harus diperhatikan oleh pemimpin dan divisi HRD (Human Resource Department). Prestasi kerja merupakan umpan balik yang diharapkan dapat mengidentifikasi kebutuhan pengembangan karier dan pelatihan khusus yang harus diberikan pada karyawan. Selain itu, pestasi kerja dapat membantu mengevaluasi proses rekrutmen, seleksi, orientasi, dan prosedur penempatan karyawan.

Setiap organisasi selalu berusaha meningkatkan prestasi kerja karyawannya. Salah satu cara yang bisa dilakukan dengan meningkatkan disiplin kerja karyawan. Kedisiplinan harus ditegakkan dalam suatu organisasi karena semakin baik disiplin karyawan maka semakin tinggi prestasi kerja yang dapat dicapainya. Tanpa disiplin karyawan yang baik maka sulit organisasi untuk mencapai hasil yang optimal.

Dalam dunia kerja, disiplin memiliki manfaat yang cukup besar bagi kepentingan organisasi maupun karyawannya. Pelaksanaan program kedisiplinan yang dijalankan didalam perusahaan akan membantu untuk mengarahkan dan mengontrol segala tindakan dan perilaku para karyawan untuk selalu ada dalam ketentuanketentuan yang telah berlaku. (Melati, Soepono, \& Firdaus, 2014) Bagi organisasi, dengan adanya disiplin kerja akan menjamin terpeliharanya tata tertib dan kelancaran pelaksanaan tugas, sehingga diperoleh hasil yang optimal. Bagi karyawan dengan adanya sikap disiplin kerja dapat mempermudah seseorang dalam mengerjakan tugasnya. Disiplin kerja juga merupakan bentuk pengendalian diri karyawan dan pelaksanaan yang teratur sehingga dapat menunjukkan tingkat kesungguhan tim kerja dalam sebuah organisasi.

Dengan mengembangkan budaya organisasi yang tepat perusahaan dapat menghadapi tantangan eksternal 
dan memelihara kebutuhan internalnya. Suatu organisasi perlu membangun dan mengembangkan budaya organisasi yang adaptif terhadap perubahan, lingkungan, dan memiliki sumber daya manusia yang kompeten dalam rangka pencapaian tujuan organisasi.

Budaya organisasi pun dapat mempengaruhi perilaku karyawan baik perilaku positif maupun negatif. Hal tersebut terwujud dalam perilaku sehari-hari dalam bekerja dan akan membentuk prestasi kerja seseorang dalam bekerja dan mempengaruhi kinerja perusahaan. (Fahmi, Agung, \& Rachmatullaily, 2018)

Pemimpin yang mampu mengembangkan budaya organisasinya secara efektif akan memiliki kualitas dan keyakinan tertentu sehingga dapat meningkatkan kinerja karyawan dan organisasi. Budaya organisasi yang kuat menjadi suatu keunggulan suatu organisasi jika seluruh anggotanya memahami dan menerapkan budaya tersebut dalam tindakan yang tepat.

Oleh karena itu, berdasarkan latar belakang permasalahan tersebut diatas penulis menyusun skripsi yang berjudul "Pengaruh Disiplin dan Budaya Organisasi Terhadap Prestasi Kerja Pegawai Dinas Perindustrian dan Perdagangan Kota Bogor"

Rumusan Masalah

Adapun rumusan masalah dalam penelitian ini, sebagai berikut (1) Bagaimana pengaruh disiplin terhadap prestasi kerja pegawai Dinas Perindustrian dan Perdagangan Kota Bogor? (2) Bagaimana pengaruh budaya organisasi terhadap prestasi kerja pegawai Dinas Perindustrian dan
Perdagangan Kota Bogor?

Bagaimana pengaruh disiplin dan budaya organisasi tehadap prestasi kerja pegawai Dinas Perindustrian dan Perdagangan Kota Bogor?

\section{Tujuan Penelitian}

Adapun tujuan dalam penelitian ini, sebagai berikut : (1) Untuk mengetahui bagaimana pengaruh disiplin terhadap prestasi kerja pegawai Dinas Perindustrian dan Perdagangan Kota Bogor. (2) Untuk mengetahui bagaimana pengaruh budaya organisasi terhadap prestasi kerja pegawai Dinas Perindustrian dan Perdagangan Kota Bogor. (3) Untuk mengetahui bagaimana pengaruh disiplin dan budaya organisasi terhadap prestasi kerja pegawai Dinas Perindustrian dan Perdagangan Kota Bogor.

\section{Metode Penelitian}

\section{Jenis Penelitian}

Dalam melakukan penelitian ini menggunakan metode kuantitatif dan desain konklusif dengan harapan untuk memperoleh hubungan atau pengaruh dari variabel yang diteliti yaitu disiplin sebagai variabel independen $\left(\mathrm{X}_{1}\right)$ dan budaya organisasi sebagai variabel independen $\left(\mathrm{X}_{2}\right)$, terhadap variabel prestasi kerja sebagai variabel dependen (Y).

2. Populasi dan Sampel

Jumlah populasi pegawai PNS Dinas Perindustrian dan Perdagangan Kota Bogor sebanyak 59 orang. Sehingga sampel yang digunakan sebanyak 51 orang. Dengan perhitungan sampel menurut slovin dan menggunakan tingkat kesalahan 0,05 . 


\section{Sumber Data}

Sumber data yang digunakan dalam penelitian ini yaitu data primer dan data sekunder. Menurut Sujarweni (2015, 89), data primer adalah data yang diperoleh dari responden melalui kuesioner, kelompok fokus, dan panel, atau juga data hasil wawancara peneliti dengan narasumber. Sedangkan data sekunder adalah data yang didapat dari catatan, buku, dan majalah berupa laporan keuangan, publikasi perusahaan, laporan pemerintah, artikel, buku-buku sebagai teori, majalah, dan lain.

4. Teknik atau Cara Pengumpulan

Data

Cara pengumpulan data yang digunakan dalam penelitian ini yaitu wawancara, observasi, dan kuisioner. Kuisioner memiliki indikator dan menggunakan skala likert yang memiliki 5 (lima) angka penilaian dengan kriteria jawaban sebagai berikut : Sangat Setuju (SS)/ Sering (S) Skor 5, Setuju (S)/ Pernah (P) Skor 4, Ragu-ragu (R)/Kadangkadang (K) Skor 3, Tidak Setuju (TS)/ Jarang (J) Skor 2, dan Sangat Tidak Setuju (STS)/Tidak Pernah (TP) Skor 1.

\section{Metode Analisis}

a. Analisis Deskriptif

Menurut Sujarweni (2015, 113), statistik deskriptif berusaha menggambarkan berbagai karakteristik data yang berasal dari suatu sampel. Statistik deskriptif seperti mean, median, modus, persentil, desil, quartil, dalam bentuk analisis angka maupun gambar atau diagram.

Tujuan analisis deskriptif dalam penelitian ini untuk mengetahui dan menggambarkan nilai rata-rata dari jawaban atau persepsi responden berdasarkan dari data yang telah dikumpulkan melalui data kuisioner terkait variabelvariabel yang diteliti dalam penelitian ini, yaitu variabel $\mathrm{X}_{1}$ (Disiplin), variabel $\mathrm{X}_{2}$ (Budaya Organisasi), variabel Y (Prestasi Kerja).

b. Uji Validitas dan Reliabilitas

Menurut Sugiyono (2018, 202-203) instrumen yang valid berarti alat ukur yang digunakan untuk mendapatkan data (mengukur) itu valid. Valid berarti instrumen tersebut dapat digunakan untuk mengukur apa yang seharusnya diukur. Instrumen reliabilitas adalah instrumen yang bila digunakan beberapa kali untuk mengukur obyek yang sama, akan menghasilkan data yang sama.

c. Uji Asumsi Klasik

Uji Normalitas

Menurut Sujarweni (2015, 52-55) uji Normalitas data ini sebaiknya dilakukan sebelum data diolah berdasarkan modelmodel penelitian. Uji Normalitas ini bertujuan untuk mengetahui distribusi data dalam variable yang akan digunakan dalam penelitian. Data yang baik dan layak digunakan dalam penelitian adalah data yang memiliki distribusi normal. 
Uji Homogenitas

Menurut Purnomo (2017, 100-105) uji homogenitas digunakan untuk mengetahui varian populasi apakah antara dua kelompok data atau lebih memiliki varian yang sama atau berbeda.

Uji Linieritas

Menurut Sujarweni (2015, 56-61) uji linieritas ini untuk melihat spesifikasi model yang digunkan benar atau tidak. Dengan uji ini akan diperoleh informasi model empiris sebaiknya linier, kuadran, atau kubik.

d. Analisis Inferensial

Korelasi

Menurut Riduwan \& Sunarto $(2015,80-81)$, salah satu analisis korelasi yaitu korelasi PPM (Pearson Product Moment). Tujuannya untuk mengetahui derajat hubungan dan kontribusi variabel bebas (independent) dengan variabel terikat (dependent). Teknik analisis ini menggunakan data interval dan ratio dengan persyaratan tertentu

Koefisien Determinasi

Menurut Riduwan \& Sunarto (2015, 81), koefisien determinasi digunakan untuk menyatakan besar kecilnya sumbangan variabel $\mathrm{X}$ terhadap variabel Y

Regresi Linear Sederhana

Menurut Riduwan \& Sunarto (2015, 96-97), regresi atau peramalan adalah suatu proses memperkirakan secara sistematis tentang apa yang paling mungkin terjadi di masa yang akan datang berdasarkan informasi masa lalu dan sekarang yang dimiliki agar kesalahannya dapat diperkecil.

Regresi Linear Berganda

Menurut Riduwan \& Sunarto (2015, 108-110), analisis regresi ganda adalah pengembangan dari analisis regresi sederhana. Kegunannya untuk meramalkan nilai variabel terikat (Y) apabila varibel bebas (X) miNPMal dua atau lebih $\left(\mathrm{X}_{1}\right),\left(\mathrm{X}_{2}\right),\left(\mathrm{X}_{3}\right), \ldots,\left(\mathrm{X}_{\mathrm{n}}\right)$.

e. Uji Hipotesis

Uji T

Setelah melakukan analisis korelasi maka perlu menghitung uji signifikansi. Menurut Riduwan \& Sunarto $(2015,81)$, uji signifikansi berfungsi untuk mencari hubungan variabel $\mathrm{X}$ terhadap Y.

Uji F

Menurut Riduwan \& Sunarto (2015, 86-87), analisis korelasi ganda berfungsi untuk mencari besarnya hubungan dan kontribusi dua variabel bebas (X) atau lebih secara simultan (bersama-sama) dengan variabel terikat (Y).

\section{Hasil Dan Pembahasan}

1. Uji Validias dan Reliabilitas

Penelitian ini menggunakan taraf signifikansi 95\% $(\alpha=0,05)$, dan $\mathrm{n}=51-2$ $=49$ diperoleh $r_{\text {tabel }}=0.276$, maka dapat dikatakan bahwa suatu instrumen adalah valid. Dengan membandingkan nilai pada kolom Corrected Item-Total Correlation ( $\mathrm{r}$ hitung) dengan $r$ tabel. Dari data hasil penelitian menunjukkan $>r_{\text {tabel }}$ dapat 
dikatakan bahwa keseluruhan item penelitian adalah valid untuk digunakan sebagai instrumen dalam penelitian

Dengan melihat data hasil penelitian menunjukkan Cronbach's Alpha >0,60 dapat disimpulkan bahwa pertanyaan dalam kuesioner variabel Disiplin $\left(\mathrm{X}_{1}\right)$, Budaya Organisasi $\left(\mathrm{X}_{2}\right)$, dan Prestasi Kerja (Y) adalah reliabel dan dapat diterima.

2. Uji Asumsi Klasik

Normalitas

Data yang digunakan dalam penelitian ini memiliki distribusi normal, karena dapat dilihat pada baris Asymp. Sig. (2-tailed) Disiplin > 0,05 yaitu sebesar 0,097. Asymp. Sig. (2-tailed) Budaya Organisasi > 0,05 yaitu sebesar 0,200. Asymp. Sig. (2-tailed) Prestasi Kerja > 0,05 yaitu sebesar 0,082

Homogenitas

Nilai signifikansi variabel Prestasi Kerja (Y) berdasarkan variabel Disiplin $\left(\mathrm{X}_{1}\right)=0,187>0,05$, maka dapat disimpulkan bahwa data tersebut mempunyai variabel yang sama atau homogen. Sedangkan nilai signifikansi variabel Prestasi Kerja (Y) berdasarkan variabel Budaya Organisasi $\left(\mathrm{X}_{2}\right)=0,101<$ 0,05, maka dapat disimpulkan bahwa data tersebut mempunyai variabel yang sama atau homogen.

Linieritas

Pada uji linieritas diperoleh nilai variabel Disiplin $\left(\mathrm{X}_{1}\right)$ dengan Prestasi Kerja (Y) adalah $\mathrm{F}_{\text {hitung }}=0,404<\mathrm{F}$ tabel $=$ 4,04 dan nilai variabel Budaya Organisasi $\left(\mathrm{X}_{2}\right)$ dengan Prestasi Kerja $(\mathrm{Y})$ adalah $\mathrm{F}$ hitung $=1,608<\mathrm{F}$ tabel $=4,04$, maka dapat disimpulkan bahwa terdapat hubungan linier secara signifikan diantara keduanya.

3. Analisis Pengaruh Antara Disiplin $\left(\mathrm{X}_{1}\right)$ dan Prestasi Kerja (Y)
Analisis Korelasi

Dari hasil perhitungan menunjukan nilai $R=0,628$ terletak pada interval 0,60 - 0,799 (Kuat), hal ini menunjukan bahwa hubungan antara variabel $\mathrm{X}_{1}$ (persepsi terhadap Disiplin) dan $\mathrm{Y}$ (persepsi terhadap Prestasi Kerja) adalah Kuat dan positif. Berarti apabila $\mathrm{X}_{1}$ naik maka $\mathrm{Y}$ juga naik.

Analisis Regresi

Berdasarkan hasil perhitungan koefisien regresi dapat diketahui bahwa persamaan regresi yang terbentuk adalah $\mathrm{Y}$ $=15,054+0,711 \mathrm{X}_{1}$. Interprestasi atau konstanta sebesar 15,054. Berarti apabila variabel bebas $\mathrm{X}_{1}$ (Disiplin) sama dengan nol, maka besarnya variabel $\mathrm{Y}$ (Prestasi Kerja) adalah 15,054. Arah pengaruh dan koefisien regresi variabel $\mathrm{X}_{1}$ (Disiplin) sebesar 0,711 ini berarti pengaruh Disiplin $\left(\mathrm{X}_{1}\right)$ terhadap Prestasi Kerja (Y) adalah positif atau setiap kenaikan nilai skor variabel $\mathrm{X}_{1}$ Disiplin sebesar 1 , maka akan meningkatkan nilai skor variabel $\mathrm{Y}$ (Prestasi Kerja) sebesar 0,711.

\section{Analisis Koefisien Determinasi}

Hasil koefisien determinasi sebesar 0,394 atau $(39,4 \%)$ dan koefisien determinasi yang disesuaikan sebesar 0,382 atau $(38,2 \%)$. Karena persamaan regresi menggunakan banyak variabel independen, maka koefisien yang digunakan untuk menjelaskan persamaan ini adalah koefisien determinasi yang disesuaikan sebesar 0,382 atau $(38,2 \%)$ memberikan arti bahwa besarnya pengaruh Disiplin terhadap Prestasi Kerja sebesar $38,2 \%$ sedangkan sisanya $61,8 \%$ dipengaruhi oleh faktor-faktor lain yang tidak dimasukan dalam penelitian ini.

Uji Hipotesis Parsial (Uji T)

$\mathrm{T}_{\text {hitung }}=5,649>\mathrm{T}$ tabel $=1,676$ maka Ho ditolak (Ha diterima) berarti bahwa terdapat pengaruh yang signifikan antara 
Disiplin $\left(\mathrm{X}_{1}\right)$ dan terhadap Prestasi Kerja (Y).

4. Analisis Pengaruh Antara Budaya Organisasi $\left(\mathrm{X}_{2}\right)$ dan Prestasi Kerja (Y) Analisis Korelasi

Dari hasil perhitungan tersebut menunjukan nilai $\mathrm{R}=0,551$ terletak pada interval $\quad 0,40 \quad-\quad 0,599 \quad$ (Cukup kuat/Sedang), hal ini menunjukan bahwa hubungan antara variabel $\mathrm{X}_{1}$ (persepsi terhadap Disiplin) dan $\mathrm{Y}$ (persepsi terhadap Prestasi Kerja) adalah sedang dan positif. Berarti apabila $X_{1}$ naik maka $Y$ juga naik.

\section{Analisis Regresi}

Berdasarkan perhitungan koefisien regresi diketahui bahwa persamaan regresi yang terbentuk adalah $\mathrm{Y}=20,827+0,500$ $\mathrm{X}_{2}$. Interprestasi atau konstanta sebesar 20,827 berarti apabila variabel bebas $X_{2}$ (Budaya Organisasi) sama dengan nol, maka besarnya variabel Y (Prestasi Kerja) adalah 20,827. Arah pengaruh dan koefisien regresi variabel $\mathrm{X}_{2}$ (Budaya Organisasi) sebesar 0,500 ini berarti pengaruh Budaya Organisasi $\left(\mathrm{X}_{2}\right)$ terhadap Prestasi Kerja (Y) adalah positif atau setiap kenaikan nilai skor variabel $\mathrm{X}_{2}$ Budaya Organisasi sebesar 1, maka akan meningkatkan nilai skor variabel $Y$ (Prestasi Kerja) sebesar 0,500.

Analisis Koefisien Determinasi

Hasil koefisien determinasi sebesar 0,303 atau $(30,3 \%)$ dan koefisien determinasi yang disesuaikan sebesar 0,289 atau $(28,9 \%)$. Karena persamaan regresi menggunakan banyak variabel independen, maka koefisien yang digunakan untuk menjelaskan persamaan ini adalah koefisien determinasi yang disesuaikan sebesar 0,289 atau $(28,9 \%)$ memberikan arti bahwa besarnya pengaruh Budaya Organisasi terhadap Prestasi Kerja sebesar $28,9 \%$ sedangkan sisanya $71,1 \%$ dipengaruhi oleh faktor-faktor lain yang tidak dimasukan dalam penelitian ini.

Uji Hipotesis Parsial (Uji T)

$$
\mathrm{T}_{\text {hitung }}=4,620>\mathrm{T} \text { tabel }=1.676
$$

maka Ho ditolak (Ha diterima) berarti bahwa terdapat pengaruh yang signifikan antara Budaya Organisasi $\left(\mathrm{X}_{2}\right)$ dan terhadap Prestasi Kerja (Y).

5. Analisis Pengaruh Antara Disiplin $\left(\mathrm{X}_{1}\right)$ dan Budaya Organisasi $\left(\mathrm{X}_{2}\right)$ terhadap Prestasi Kerja (Y)

Analisis Korelasi

Dari hasil perhitungan tersebut menunjukan nilai $\mathrm{R}=0,752$ terletak pada interval $0,60-0,799$ (Kuat), hal ini menunjukan bahwa pengaruh antara variabel $\mathrm{X}_{1}$ (persepsi terhadap Disiplin) dan variabel $\mathrm{X}_{2}$ (persepsi terhadap Budaya Organisasi) dan Y (persepsi terhadap Prestasi Kerja) adalah kuat dan positif. Berarti apabila $X_{1}$ dan $X_{2}$ naik maka $Y$ juga naik.

\section{Analisis Regresi}

Berdasarkan perhitungan koefisien regresi dapat diketahui bahwa persamaan regresi yang terbentuk adalah $\mathrm{Y}=2,472+$ $0,597 \mathrm{X}_{1}+0,386 \mathrm{X}_{2}$. Interprestasi atau konstanta sebesar 2,472 berarti apabila variabel bebas $\mathrm{X}_{1}$ (Disiplin) dan $\mathrm{X}_{2}$ (Budaya Organisasi) sama dengan nol, maka besarnya variabel Y (Prestasi Kerja) adalah 2,472. Dengan kata lain, jika variabel bebas $\mathrm{X}_{1}$ (Disiplin) dan $\mathrm{X}_{2}$ (Budaya Organisasi) nilainya dianggap nol berarti besarnya variabel $\mathrm{Y}$ (Prestasi Kerja) adalah 2,472. Arah pengaruh dan koefisien regresi variabel $\mathrm{X}_{1}$ (Disiplin) sebesar 0,597 ini berarti pengaruh Disiplin $\left(\mathrm{X}_{1}\right)$ terhadap Prestasi Kerja (Y) adalah positif atau setiap kenaikan nilai skor variabel $\mathrm{X}_{1}$ Disiplin sebesar 1, maka akan meningkatkan nilai skor variabel Y (Prestasi Kerja) sebesar 0,597. Arah pengaruh dan koefisien regresi variabel $\mathrm{X}_{2}$ 
(Budaya Organisasi) sebesar 0,386 ini berarti pengaruh Budaya Organisasi $\left(\mathrm{X}_{2}\right)$ terhadap Prestasi Kerja (Y) adalah positif atau setiap kenaikan nilai skor variabel $\mathrm{X}_{2}$ Budaya Organisasi sebesar 1, maka akan meningkatkan nilai skor variabel $\mathrm{Y}$ (Prestasi Kerja) sebesar 0,386.

\section{Analisis Koefisien Determinasi}

Hasil koefisien determinasi sebesar 0,566 atau $(56,6 \%)$ dan koefisien determinasi yang disesuaikan sebesar 0,548 atau $(54,8 \%)$. Karena persamaan regresi menggunakan banyak variabel independen, maka koefisien yang digunakan untuk menjelaskan persamaan ini adalah koefisien determinasi yang disesuaikan sebesar 0,548 atau $(54,8 \%)$ memberikan arti bahwa besarnya pengaruh Disiplin $\left(\mathrm{X}_{1}\right)$ dan Budaya Organisasi $\left(\mathrm{X}_{2}\right)$ terhadap Prestasi Kerja (Y) sebesar 54,8\% sedangkan sisanya 45,2\% dipengaruhi oleh faktor-faktor lain yang tidak dimasukan dalam penelitian ini.

Uji Hipotesis Simultan (Uji F)

$$
\mathrm{F}_{\text {hitung }}=31,256>\mathrm{F} \text { tabel }=3,19
$$

maka Ho ditolak (Ha diterima) berarti bahwa terdapat pengaruh yang signifikan antara Disiplin $\left(\mathrm{X}_{1}\right)$ dan Budaya Organisai $\left(\mathrm{X}_{2}\right)$ terhadap Prestasi Kerja (Y).

\section{Kesimpulan dan Saran Kesimpulan}

Penelitian ini bertujuan untuk mengetahui Pengaruh Disiplin dan Budaya Organisasi terhadap Prestasi Kerja Pegawai Dinas Perindustrian dan Perdagangan Kota Bogor. Berdasarkan hasil pembahasan dan analisis maka kesimpulan dari penelitian ini adalah sebagai berikut :

1. Pengaruh Disiplin terhadap Prestasi Kerja pada Dinas Perindustrian dan Perdagangan Kota Bogor menunjukan nilai $\mathrm{R}=0,628$ terletak pada interval $0,600-0,799$ (Kuat), hal ini menunjukan bahwa terdapat pengaruh antara Disiplin terhadap Prestasi Kerja dengan hasil koefisien determinasi sebesar 0,394 atau $(39,4 \%)$ dan koefisien determinasi yang disesuaikan sebesar 0,382 atau $(38,2 \%)$. Hasil analisis regresi $\quad \mathrm{Y}=$ $15,054+0,711 \mathrm{X}_{1}$ dan uji $\mathrm{T}$ hipotesis parsial dengan $\mathrm{T}$ hitung $=5,649>\mathrm{T}$ tabel $=1,676$ berarti bahwa terdapat pengaruh yang signifikan antara Disiplin $\left(\mathrm{X}_{1}\right)$ dan terhadap Prestasi Kerja (Y).

2. Pengaruh Budaya Organisasi terhadap Prestasi Kerja Pegawai pada Dinas Perindustrian dan Perdagangan Kota Bogor menunjukan nilai $\mathrm{R}=0,551$ terletak pada interval 0,40 - 0,599 (Cukup Kuat/Sedang), hal ini menunjukan bahwa terdapat pengaruh antara Budaya Organisasi terhadap Prestasi Kerja dengan hasil koefisien determinasi sebesar 0,303 atau $(30,3 \%)$ dan koefisien determinasi yang disesuaikan sebesar 0,289 atau $(28,9 \%)$. Hasil analisis regresi $\mathrm{Y}=20,827+0,500$ $\mathrm{X}_{2}$ dan uji $\mathrm{T}$ hipotesis persial dengan $\quad \mathrm{T}$ hitung $=$ $4,620>\mathrm{T}$ tabel $=1,676$ berarti bahwa terdapat pengaruh yang signifikan antara Budaya Organisasi $\left(\mathrm{X}_{2}\right)$ dan terhadap Prestasi Kerja (Y).

3. Pengaruh Disiplin dan Budaya Organisasi terhadap Prestasi Kerja Pegawai pada Dinas Perindustrian dan Perdagangan Kota Bogor menunjukan nilai $\mathrm{R}=0,752$ 
terletak pada interval $0,60-0,799$ (Kuat), hal ini menunjukan bahwa terdapat pengaruh antara Disiplin dan Budaya Organisasi terhadap Prestasi Kerja dengan hasil koefisien determinasi sebesar 0,566 atau $(56,6 \%)$ dan koefisien determinasi yang disesuaikan sebesar 0,548 atau $(54,8 \%)$. Hasil analisis regresi $\quad \mathrm{Y}=$ $2,472+0,597 X_{1}+0,386 X_{2}$ dan uji $\mathrm{F}$ hipotesis simultan dengan $\mathrm{F}_{\text {hitung }}=31,256>\mathrm{F}_{\text {tabel }}=3,19$ berarti bahwa terdapat pengaruh yang signifikan antara Disiplin $\left(\mathrm{X}_{1}\right)$ dan Budaya Organisasi $\left(\mathrm{X}_{2}\right)$ terhadap Prestasi Kerja (Y).

Saran

Berdasarkan hasil pembahasan dan kesimpulan di atas maka saran yang dapat diberikan berkaitan dengan tentang Pengaruh Disiplin dan Budaya Organisasi terhadap Prestasi Kerja Pegawai adalah sebagai berikut :

1. Variabel Disiplin yang diteliti dalam penelitian ini menunjukkan pengaruh yang signifikan terhadap Prestasi Kerja Pegawai. Sebaiknya instansi mempertahankan dan meningkatkan kedisiplinan, agar setiap pegawai memiliki usaha dan upaya untuk mencapai atau melebihi target pekerjan sehingga berpengaruh pada prestasi kerja setiap pegawai.

2. Variabel Budaya Organisasi yang diteliti dalam penelitian ini menunjukkan pengaruh yang signifikan terhadap Prestasi Kerja. Sebaiknya instansi lebih memperhatikan penerapan budaya organisasi. Bagi atasan/pemimpin sebaiknya lebih mengarahkan para pegawainya tentang pentingnya penerapan budaya organisasi di tempat kerja. Dengan adanya penerapan budaya organisasi yang baik dan tepat dapat mendukung prestasi kerja pegawai.

3. Prestasi kerja pegawai perlu diperhatikan oleh organisasi karena dapat mendukung pencapaian tujuan organisasi dan dapat meningkatkan kinerja organisasi.

\section{Daftar Pustaka}

Andreas, D. (t.t.). Indeks SDM Bank Dunia 2018: Singapura Peringkat 1, Indonesia ke-87. Diambil 21 Februari 2019, dari Tirto.id website: https://tirto.id/indeks-sdmbank-dunia-2018-singapuraperingkat-1-indonesia-ke-87-c6jN

Fahmi, M., Agung, S., \& Rachmatullaily, T. (2018). Gaya Kepemimpinan Dan Budaya Organisasi Terhadap Kinerja Karyawan. 20.

Melati, R., Soepono, \& Firdaus, M. A. (2014). Pengaruh Disiplin Dan Kepuasan Kerja Terhadap Prestasi Kerja Karyawan Pada PT. Adi Citra Megah. 23.

Purnomo, R. A. (2017). Analisis Statistik Ekonomi Dan Bisnis Dengan Spss. Ponorogo: Cv. Wade Group.

Riduan, \& Sunarto. (2015). Pengantar Statistika Untuk Penelitian: Pendidikan, Sosial, Komunikasi, Ekonomi, Dan Bisnis. Bandung: Cv. Alfabeta.

Sugiyono. (2018). Metode Penelitian Manajemen. Bandung: $\mathrm{Cv}$. Alfabeta. 
Sujarweni, V. W. (2015). Spss Untuk

Penelitian. Yogyakarta: Pustaka Baru Press.

Sujarwerni, V. W. (2015). Metodologi Penelitian-Bisnis \& Ekonomi. Yogyakarta: Pt. Pustaka Baru. 